\title{
Impact of Classroom Environment on Student's Attitude Towards School
}

\author{
LUBNA NAZNEEN \\ Lecturer, Department of Psychology \\ Islamia College Peshawar \\ nazneenbnu@gmail.com \\ DR. SUMMAYYA HAYAT \\ Associate Professor, Department of Psychology \\ University of Peshawar \\ Summiyaahmad@hotmail.com \\ DR. JUNAID ATHAR KHAN \\ Assistant Professor, Institute of Business Studies and Leadership \\ Abdul Wali Khan University, Mardan \\ Junaid@awkum.edu.pk
}

\begin{abstract}
Current study was undertaken to determine the effect of psychosocial classroom environment on student's attitude towards school. Using cluster sampling technique 203 students' including 97 females' and 107 males, age range 12-14 years were taken from class $7^{\text {th }}$ and $8^{\text {th }}$ of different government and private schools in Peshawar. What Is Happening In This Class? (WIHIC) questionnaire (Fraser, McRobbie \& Fisher, 1996) and an Attitude toward School Scale (Anderson, 1999) were administered for data collection. Psychosocial classroom environment was found to be a significant predictor of students' attitude towards school. There were also some gender differences on different classroom environment variables and their impact on student's attitude towards school.
\end{abstract}

Key Words: Classroom Environment, Students, Attitude

\section{Introduction}

Human beings are given the ability to learn knowledge and transmit it to their future generations and this is the process we actually consider as education. Many researcheshave been conducted in the field of education in order to throw light on the role it plays in human development. It is a very important element of our process of psychosocial development and successful adjustment to society. The important agents providing education are schools, colleges and universities etc, but unfortunately nowadays, it has become a common observation that students in our schools show a lack of interest in studies and thus have to face frequentfailures, and as a result of such failures they at the end decide to leave their studies or at least leave the school.Students who quit the school actually have faced many problems in the field of academics and learning before their actual decision to quit the school or discontinue their studies (Rumberger, 
2004; Psacharopoulos, 2007). Important factors include school environment, the attitude of teachers and friends (Cabus, 2011), student's own interest in studies, their ability and level of achievement (Sartarelli, 2011)In the current scenario now it is much needed to design such strategies or academic activities by school teachers and psychologists which can enhance the students level of interest in their school as well as learning(Candeias\&Rebelo, 2010).Lewy (1986) defined attitude towards school as a construct "including the subject's behaviors, their expression regarding to affection and judgments, favorable or unfavorable, for the school and school experiences".

Schools which arrange more co curricular activities and also involve students in other learning based activities are better able to evoke the interest of their students in education and learning. Another factor which can enhance student's attitude towards school is the parental participation and involvement in the school decision making process (Abreu, Veiga, Antunes \& Ferreira, 2006). At the same time support from significant others at home and school also enhance academic values and positive attitudes towards school. These attitudes are largely depicted through the level of relationships they have with their teachers and school mates and the amount of involvement they show in academic and extracurricular activities at school. Moreover cultural background, type and intensity of bonds with family members, family support, achievement level in the past highly determines their attitudes towards school and also play an important role in their level of achievement in future.(Akey, 2006).

Present study has a great significance in the field of education, as it revolves around different variables making up the classroom environment and their impact on students attitudes towards school. Attitude towards school is the major factor predicting students' behavior at school, their interest in education and the resultant achievements in their academic career. Having knowledge of these classroom related factors, we can better promote the class room environments and can therefore enhance students' motivation and attitude towards learning and school. As many researchers have investigated classroom environment variables and their relationship to student's achievement and learning etc, the present study will throw light on the same aspects but in a different context. It will help us know how the classroom environment of class $7^{\text {th }}$ and $8^{\text {th }}$ of a sample of boys and girls schools in Peshawar KP show an impact on the student's attitude towards school.

\subsection{0bjectives of the Research}

- To study the role of class room environment in shaping student's attitude towards school.

- To ascertain the impact of teacher's support and equity on student's attitude towards school.

- To identify the role of student's cohesiveness in their attitude towards school.

- To find out gender differences on different variables in the class room environment scale, and their impact on student's attitude towards school.

\section{Literature Review}

Students' perception of their teachers is a very important factor to affect their academic performance in the field of education. High and low achievers were compared for how they perceive their teacher's behavior and what was their resultant level of self esteem (Kususanto, Ismail \& Jamil 2010). Improved systems of education have been introduced through extensive researches in order to pass on important knowledge efficiently and 
ensure both academic and psychosocial development of children within the context of classroom environment. Moos's (1974) has classified human environments into three types.

\subsection{Relationship Dimensions}

This dimension indicates the strength and quality of the relationship, the level of involvement a person is having towards his/her environment. It also describes the level of support and cohesiveness which members of a group show for each other.

\subsection{Personal Development Dimensions}

This refers to the level of a person's involvement and interest in his/her own self enhancement and growth.

\subsection{System Maintenance and System Change Dimensions}

This refers to orderliness of surroundings, clearly explains future prospects, and is controlling and sensitive to change. Keeping in view Moos's(1974) dimensions to provide a better classroom environment we need to focus on facilitating interaction between teacher and student giving them more and equal opportunity for self expression, building a cooperative and cohesive environment of work between classmates in order to create positive attitudes towards school and learning. Regrettably, Pakistani researchers had shown very little interest in the area. It is therefore needed to do further studies in this field to get knowledge about the important determinants of academic achievement and interest in learning in the context of Pakistan. Present study which is focused on the impact of class room environment on student's attitude towards school has also been conducted to know about the same variables. Current research on classroom environment variables and their impact on students' attitude towards school is also based on theory given by Kurt Lewin. According to Lewin (1936), all behavior and experience is an interactive function (f) of the person and the environment. His equation $B=f(P, E)$ shows that behavior is actually determined by the person's own internal traits and the factors in the environment. In the present research classroom environment variables are considered to be causing an impact on student's attitude towards school which then in turn forms their overall learning behavior. Previous research found that student's learning behavior was highly determined by the type of psychosocial environment at school (Fraser, 1999). Present study is aimed to focus on the effects of the psychosocial environment of classroom (including many teacher and student variables) on the students' attitude towards school.

\section{Methodology}

\subsection{Research Design}

As it is clear from the earlier discussion our research is based on studying the relationship of two variables on quantitative level, and it is actually based on the positivist philosophy (Saunders, Lewis, \& Thornhill, 2009). By adopting a positivist philosophy, the study therefore falls in realms of deductive approach (Saunders et al., 2009).

\subsection{Sample}

Sample of the present study consisted of 203 students age range 12-14 years from different private and government schools of Khyber Pakhtunkhwa through cluster sampling technique. 46 boys and 38 girls of class 8th were taken from Peshawar Model School and Warsak Model School respectively. Similarly 60 boys and 59 girls from 
Islamia Collegiate School and Federal Government Girls High School Peshawar Cantt were also taken as participants in this study.

\subsection{Hypotheses}

- A positive classroom environment will create a positive attitude towards school in middle school students.

- Teacher's support and equity will enhance student's attitude towards school.

- Student's showing cohesiveness at class room tasks will have a positive attitude towards school.

- There will be gender differences on different class room environment variables, and their impact on student's attitude towards school.

\subsection{Instruments}

What Is Happening In this Class? (WIHIC) questionnaire (Fraser, McRobbie \& Fisher, 1996) is a questionnaire comprised of seven subscales, each had eight items. On the basis of its high reliability and validity this scale was used in many countries for a wide range of studies (Dorman, 2008). Its seven subscales were teacher support, involvement, student cohesiveness cooperation, task orientation, investigation, and equity. For quantifying responses on each item a five point likert scale was used by the researcher. Attitudes toward School Scale (Anderson, 1999) were used to measure the student's attitude towards different aspects of school environment e.g learning, homework, grades and teachers. The scale measured positive or negative feelings of students towards their school. Age range for this scale was 12-17 years and cronbach alpha was found to be .89.The scale had fifteen items using five point likert scales for measurement.

\subsection{Procedure}

Before starting the actual study, permission was taken from principals of the concerned schools .After taking formal permission subjects were told about the purpose of the research and informed consent was also taken from them. What Is Happening In This Class? (WIHIC) questionnaire (Fraser, McRobbie \& Fisher, 1996) and an Attitude toward School Scale (Anderson, 1999) were administered on the students ages12-14 years .The questionnaires were administered in groups using cluster sampling technique and the students were helped at every point where they were unable to understand any idea given in the questions.

\section{Results}

Table 1: Psychometric Properties of Scales in the Study $(\mathrm{N}=203)$

\begin{tabular}{|c|c|c|c|c|c|c|c|}
\hline \multirow[b]{2}{*}{ Scale } & \multirow[b]{2}{*}{$\begin{array}{l}\text { No } \\
\text { items }\end{array}$} & \multirow[b]{2}{*}{ of } & \multirow[b]{2}{*}{ Mean } & \multirow[b]{2}{*}{ SD } & \multirow[b]{2}{*}{$\alpha$} & \multirow{2}{*}{$\begin{array}{l}\text { Range } \\
\text { Potential } \\
\text { actual }\end{array}$} & \multirow[b]{2}{*}{ Skew } \\
\hline & & & & & & & \\
\hline WHIC & 56 & & 188.74 & 31.98 & .92 & $56-28074-263$ & -.25 \\
\hline $\begin{array}{l}\text { Attitude } \\
\text { scale }\end{array}$ & 15 & & 57.14 & 10.38 & .83 & $15-75$ 29-75 & -.30 \\
\hline
\end{tabular}


Table 2: Simple Regression Analysis of Class room Environment predicting Attitude towards school $(\mathrm{N}=\mathbf{2 0 3})$

\begin{tabular}{|c|c|c|c|c|c|c|c|c|}
\hline \multirow{3}{*}{$\begin{array}{c}\text { WHICH } \\
\text { Scales }\end{array}$} & \multirow{2}{*}{\multicolumn{2}{|c|}{$\begin{array}{c}\text { Male } \\
(n=106)\end{array}$}} & \multirow{2}{*}{\multicolumn{2}{|c|}{$\begin{array}{c}\text { Female } \\
(\mathbf{n}=97)\end{array}$}} & \multirow{3}{*}{$\mathbf{t}(\mathbf{2 0 1})$} & \multirow{3}{*}{$\mathbf{p}$} & \multicolumn{2}{|c|}{ CI( 95\%) } \\
\hline & & & & & & & \multirow[t]{2}{*}{$\mathbf{L L}$} & \multirow[t]{2}{*}{$\mathbf{U L}$} \\
\hline & $\mathbf{M}$ & SD & $\mathbf{M}$ & SD & & & & \\
\hline studcoh & 29.12 & 6.25 & 27.60 & 7.45 & 1.57 & .117 & -.38 & 3.14 \\
\hline teachsupp & 28.57 & 6.84 & 25.04 & 6.21 & 3.83 & .000 & 1.71 & 5.34 \\
\hline Involvement & 26.07 & 6.59 & 25.60 & 5.76 & 0.53 & .593 & -1.25 & 2.18 \\
\hline Investigation & 19.93 & 6.41 & 22.61 & 6.56 & -2.94 & .004 & -4.48 & -0.88 \\
\hline Taskorien & 33.21 & 5.68 & 28.35 & 9.06 & 4.62 & .000 & 2.79 & 6.94 \\
\hline \multirow[t]{2}{*}{ cooperation } & 26.67 & 5.68 & 28.53 & 9.35 & -1.72 & .086 & -3.97 & 0.26 \\
\hline & \multicolumn{2}{|l|}{ B } & Std. Error & $\beta$ & & $\mathbf{t}$ & \multicolumn{2}{|c|}{ sig } \\
\hline (Constant) & \multicolumn{2}{|l|}{27.19} & 3.82 & & \multicolumn{2}{|c|}{7.10} & \multicolumn{2}{|c|}{.000} \\
\hline WHICtotal & \multicolumn{2}{|l|}{.15} & .02 & .48 & \multicolumn{2}{|c|}{7.94} & \multicolumn{2}{|c|}{.000} \\
\hline
\end{tabular}

$R^{2}=0.23$, WHIC: What Is Happening in this Class questionnaire: 23

Table 2 shows the impact of a total classroom environment on students' attitude towards school. Results show that class room environment is a significant predictor of students' attitude towards school. 


$\begin{array}{lllllllll}\text { Equity } & 30.70 & 26.79 & 6.44 & 6.85 & 4.19 & .000 & 2.07 & 5.75\end{array}$

Table Multiple Regression Analysis of Class room Environment Sub Scales predicting Attitude towards $\operatorname{school}(\mathbf{N}=\mathbf{2 0 3})$

$R^{2}=0.29$, Stucoh: Students' Cohesiveness, Teachsupp:Teachers 'Support

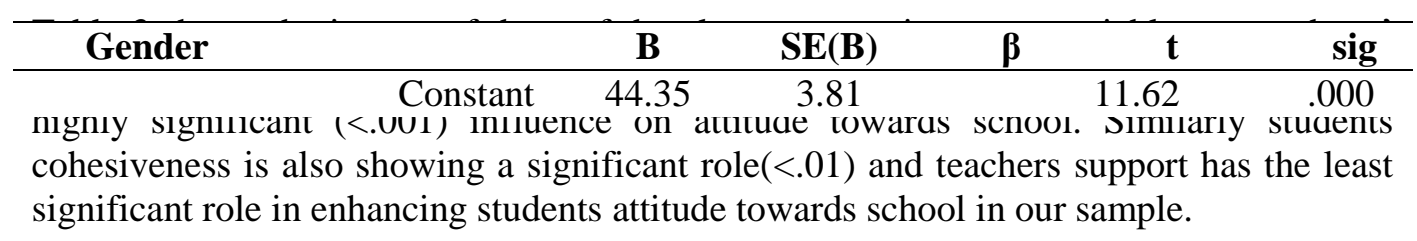

Table 4: Hierachical Regression Analysis of Class Room Environment Variables Predicting Attitude towards School

\begin{tabular}{cccccc}
\hline & B & Std. Error & $\boldsymbol{\beta}$ & $\mathbf{t}$ & sig \\
\hline (Constant) & 28.17 & 3.31 & & 8.50 & .000 \\
Stucoh & 0.31 & 0.09 & 0.20 & 3.23 & .001 \\
Teachsupp & 0.22 & 0.11 & 0.14 & 1.97 & .05 \\
Equity & 0.48 & 0.11 & 0.32 & 4.25 & .000 \\
\hline
\end{tabular}

Note: Stucoh: Students'Cohesivenes

Table 4 shows hierarchical regression analysis for different subscales of What Is Happening in this Class scale. These results show that only few of the variables in scale are showing a significant impact on attitude towards school. For males equity provided by the teacher in class is showing to enhance their positive attitude towards school whereas for female's student cohesiveness as well as equity both are playing a significant role in enhancing positive attitude towards school in a stepwise manner.

Table 5: Mean Difference, SD, t-value of Male and Female Students on Class Room Environment Sub Scales(N=203) 


$\begin{array}{cccccccc}\text { Male(n=106) } & 1 & \text { Equity } & 0.54 & 0.12 & 0.40 & 4.48 & .000 \\ & & & & & & & \\ \text { Female(n=97) } & 1 & \text { Constant } & 35.38 & 3.63 & & 9.73 & .000 \\ & & \text { Stucoh } & 0.63 & 0.13 & 0.45 & 4.96 & .000 \\ & 2 & \text { Constant } & 27.06 & 4.24 & & 6.37 & .000 \\ & & \text { Equity } & 0.47 & 0.14 & 0.31 & 3.36 & .001 \\ & & \text { Stucoh } & 0.47 & 0.13 & 0.33 & 3.64 & .000\end{array}$

\section{Note:Stucoh:Students 'Cohesiveness,Teachsupp:Teachers 'Support,Taskorien:Task orientation}

Table 5 shows the mean differencesof male and female students on attitude towards schoolsubscales. There are significant differences between males and females on teachers support, task orientation, equity and investigation.

\section{Discussion}

The main aim of the present research was to find out the effect of psychosocial classroom environment on students' attitude towards school. Using simple regression analysis first hypothesis was confirmed that a better classroom environment will enhance students' attitude towards school.Hoffner-Moss and Fraser (2002) discovered that if students would be providedwith their ideal classroom environment they would learn better and develop a more positive attitude towards learning and school. $2^{\text {nd }}$ hypothesis was based on two important classroom variables i.e support and equity provided by the teacher will enhance student's attitude towards school. Results showed that equity provided by the teacher had a highly significant impact whereas teacher's support had aslightly significant impact on student's attitude towards school.Closeness between student and teacher was found to be an excellent predictor of academic achievement(Birch \& Ladd, 1997). $3^{\text {rd }}$ hypothesis revolved aroundstudent's level of cohesiveness at class room tasks which was supposed to increase a positive attitude in students towards their school. This hypothesis was also confirmed at a significance level of <.01.It was concluded that if students will perform activities in groups showing care and support for each other then it will increase their positive feelings for the school. As class room environment scale has many other variables it was supposed in the last hypothesis that there will be gender differences on different classroom environment variables and their impact on students' attitude towards school. Using t-test it was found that there were significant differences between males and females on teachers support, task orientation, equity and investigation. Males showed higher means on teachers support, task orientation and equity whereas females showed higher average scores on investigation.Hierarchical regression analysis on all the classroom environment variables resulted in somewhat different results for males and females.For males equity was found to be playing a significant role in creating a positive attitude towards school whereas for females both equity and students cohesiveness were playing an important role in predicting a positive attitude towards school.

\subsection{Summary and Conclusion}

Present study was designed to measure the effect of psychosocial variables of classroom 
environment on student's attitude towards school. 203 students' including 106 males and 97 females' age range $12-14$ of class $7^{\text {th }}$ and $8^{\text {th }}$ participated in the study. What Is Happening In This Class? (WIHIC) questionnaire (Fraser, McRobbie \& Fisher, 1996) and an Attitude toward School Scale (Anderson, 1999) were used for data collection. Psychosocial classroom environment was found to be a significant predictor of students' attitude towards school. There were also some gender differences on different classroom environment variables including,equity, task orientation, investigation andteachers support. For males equity provided by the teacher whereas for females along with equity students cohesiveness was also found to be a significant predictor of positive attitude towards school. It was concluded from these findings that both student teacher as well as student-student relationships are the important factors for developing a positive feelings in students for their school.

\subsection{Limitations and Recommendations}

The major limitation of the present research was the use of a class room environment scale which contained 56 items. Students felt exhausted while completing it. Similarly the role of other variables like students personal factors and their level of achievement, were not taken into account while investigating their attitude towards school. It is recommended to design studies using a holistic approach and taking into account all possible student and other environment variables(e.g physical environment of school) which can have an influence on student's interest in learning and their attitude towards school.

\section{References}

Atchley, R.C. (2001). Continuity and Adaptation in Aging: Creating Positive Experiences. Contemporary Sociology, Vol. 30, No. 5, pp. 472-474.

Birch, S. H., \& Ladd, G. W. (1997). The teacher-child relationship and children's early school adjustment. Journal of School Psychology, 35(1), 61-79. https://doi.org/10.1016/S0022-4405(96)00029-5

Cabus, S. J. (2011). Does enhanced student commitment reduce school dropout? Evidence from two major dropout regions in the Netherlands. TIER working paper series. Candeias, A. A. \& Rebelo, N. (2010). Student' Attitudes Toward School, Learning, Competence and Motivation - the effects of gender, contextual background, school failure and development. Investigación en Convivencia Escolar. (pp. 547-55). GEU Editorial (ISBN: 978-84-9915-122-9).

Dorman, J. P. (2003). Cross-national validation of the What Is Happening In this Class? (WIHIC) questionnaire using confirmatory factor analysis. Learning Environments Research, 6, 231-245.

Fraser, B.J., Fisher, D.L. \& McRobbie, C.J. (1996). Development, validation, anduse of personal and class forms of a new classroom environment instrument. Paper presented at the annual meeting of the American Educational Research Association, New York.

Fraser, B. J. (1999). Using learning environment assessments to improve classroom and school climates. In J. Freiberg (Ed.), School Climate. (pp. 65-83). London: Falmer Press. 
Hoffner-Moss, M. C. \& Fraser, B. J. (2002). Using environment assessments in improving teaching and learning in high school biology classrooms. Paper presented at NARST annual meeting, New Orleans.

Kususanto P., Ismail, H. N., Jamil, H. (2010) Students Self Esteem and their Perception of Teacher Behavior: A study of Between Class Ability Grouping. Electronic Journal of Research in Educational Psychology, 8(2),707-724

Lewin, K. (1936). Principles of topological psychology. New York: McGrawHill.

Moos, R.H. (1979). Evaluating educational environments: procedures, measures, findings and policy implications. San Francisco, CA: Jossey-Bass.

Psacharopoulos, G. (2007). The costs of school failure - A feasibility study. European

Expert Network on Economics of Education.

Rumberger, R. W. (2004). Why students drop out of school. In Gary Orfied (Ed.)

Dropouts in America: Confronting the Graduation Rate Crisis. Cambridge, MA: Harvard Education Press, pp.131-155.

Saunders, M., Lewis, P. \& Thornhill, A. (2009) Research Methods for Business Students. Pearson, New York.

Sartarelli, M. (2011). Do Performance Targets Affect Behaviour? Evidence from Discontinuities in Test Scores in England. DoQSS Working Paper 11-02 